\title{
Electrochemical Advanced Oxidation Processes (EAOPs) for Environmental Applications
}

\author{
Mehmet A. Oturan, ${ }^{a}$, Enric Brillas ${ }^{\mathrm{b}}$ \\ a) Université de Marne la Vallée, Laboratoire des Géomatériaux et Géologie de l'Ingénieur, Cité \\ Descartes, 77454 Marne la Vallée cedex 2, France \\ b) Laboratori d'Electroquímica dels Materials i del Medi Ambient, Departament de Química \\ Física, Facultat de Química, Universitat de Barcelona, Martí i Franquès 1-11, 08028 \\ Barcelona, Spain
}

\begin{abstract}
Conventional processes for water treatment are inefficient for the remediation of wastewaters containing toxic and biorecalcitrant organic pollutants. A large number of advanced oxidation processes (AOPs) have been successfully applied to degrade pollutants present in waters. These methods are based on the generation of a very powerful oxidizing agent such as hydroxyl radical $\left({ }^{\circ} \mathrm{OH}\right)$ in solution, able to destroy organics up to their mineralization. In recent years new AOPs based on the electrochemical technology are being developed. Electrochemical advanced oxidation processes (EAOPs) are environmentally friendly emerging methods for the decontamination of wastewaters contaminated with toxic and persistent herbicides, pesticides, chlorophenols, nitrophenols, polychlorinated biphenyls, pharmaceuticals, etc. This paper reports the fundamentals, main characteristics and recent developments of EAOPs such as anodic oxidation and electro-Fenton alone and coupled with other physicochemical processes. These techniques utilize electrolytic systems such as threeelectrode divided and two-electrode undivided cells with different cathodes as working electrodes (carbon-felt or $\mathrm{O}_{2}$-diffusion cathode) and auxiliary electrodes $\left(\mathrm{Pt}, \mathrm{PbO}_{2}\right.$, boron-doped diamond (BDD) or iron anode). The effect of several experimental parameters that largely influence the degradation rate of organic pollutants is discussed. Chromatographic analyses and total organic carbon (TOC) and chemical oxygen demand (COD) measurements show a quick disappearance of initial pollutants and their aromatic and aliphatic reaction products in all cases. The great capacity of oxidation and/or mineralization of all these EAOPs to decontaminate acidic aqueous solutions of common herbicides and pesticides is described.
\end{abstract}

Keywords: AOPs, EAOPs, electro-Fenton, oxygen-diffusion cathode, carbon felt cathode, boron-doped diamond electrode, anodic oxidation, peroxi-coagulation, sonoelectro-Fenton, degradation, mineralization.

\footnotetext{
${ }^{*}$ Corresponding author. E-mail address: oturan@univ-mlv.fr
} 


\section{Introduction}

Conventional processes for water treatment are inefficient to destroy toxic and biorecalcitrant organic micropollutants. Among such persistent organic pollutants (POPs), herbicides and pesticides are compounds of great interest since they are found at relatively high contents in the aquatic environment. In the last 30 years a large variety of chemical [1-4], photochemical [5-9] and electrochemical [10-14] methods have been developed to successfully solve this problem. These procedures called advanced oxidation processes (AOPs) are based on the use of a very strong oxidizing agent such as hydroxyl radical $\left({ }^{\circ} \mathrm{OH}\right)$ with $E^{\circ}\left({ }^{\bullet} \mathrm{OH} / \mathrm{H}_{2} \mathrm{O}\right)=$ $2.8 \mathrm{~V} / \mathrm{NHE}$, which is generated in situ in the reaction medium. They are applied when conventional oxidation techniques become insufficient by kinetic reasons or because pollutants are refractory to chemical oxidation in aqueous medium or are partially oxidized yielding reaction products even with greater toxicity than that of starting pollutants. In contrast, hydroxyl radicals generated in AOPs are able to non-selectively destroy most organic and organometallic contaminants until their complete mineralization, that is, their conversion into $\mathrm{CO}_{2}$, water and inorganic ions. These radicals react rapidly with organics mainly either by abstraction of a hydrogen atom (dehydrogenation) or by addition to a nonsaturated bond (hydroxylation). For example, second-order rate constants as high as $10^{9}-10^{10} \mathrm{M}^{-1} \mathrm{~s}^{-1}$ have been determined for the hydroxylation reactions of aromatic compounds [15].

Electrochemical methods are clean and effective techniques for the direct production (anodic oxidation) or indirect generation via Fenton's reagent (electro-Fenton) of hydroxyl radicals. In anodic oxidation these radicals are formed from water oxidation (reaction (1)) on a high $\mathrm{O}_{2}$-overvoltage anode such as a $\mathrm{Pt}, \mathrm{PbO}_{2}$ and boron-doped diamond (BDD) electrode [16-19]. The electroFenton method corresponds to a coupling between the Fenton's reagent and electrochemistry $[10,11,20-22]$ in which $\mathrm{H}_{2} \mathrm{O}_{2}$ electrogenerated at the cathode reacts with $\mathrm{Fe}^{2+}$ present in the medium leading to the formation of hydroxyl radicals from Fenton's reaction (2). The effectiveness of this treatment can be enhanced if anodic oxidation with BDD is coupled to classical electro-Fenton with a carbon-felt or $\mathrm{O}_{2}$-diffusion cathode $[23,24]$.

$$
\begin{gathered}
\mathrm{H}_{2} \mathrm{O} \rightarrow{ }^{\bullet} \mathrm{OH}_{\mathrm{ads}}+\mathrm{H}^{+}+\mathrm{e}^{-} \\
\mathrm{Fe}^{2+}+\mathrm{H}_{2} \mathrm{O}_{2} \rightarrow \mathrm{Fe}^{3+}+{ }^{\bullet} \mathrm{OH}+\mathrm{OH}^{-}
\end{gathered}
$$

In our laboratories we have previously studied the electro-Fenton degradation of some aromatic compounds, mainly herbicides such as chlorophenoxy acids [11,23,25-29] and organophosphorus [30], pesticides [22], dyes [31,32], industrial pollutants $[29,31,33,34]$ and pharmaceuticals as emerging pollutants $[24,35,36]$ using different electrolytic cells. The outstanding oxidizing power of electro-Fenton processes is explained by the fast reaction of organics with ${ }^{\circ} \mathrm{OH}$ formed in the medium from reaction (2) and in some cases, at the anode from reaction (1), being the former reaction enhanced by the additional regeneration of 
$\mathrm{Fe}^{2+}$ from cathodic reduction of $\mathrm{Fe}^{3+}$. The mineralization rate of electrolyzed solutions were determined from the measurement of their chemical oxygen demand (COD) and/or total organic carbon (TOC). To know the evolution of the chemical composition of treated solutions, the decay kinetics of starting pollutants were followed by high-performance liquid chromatography (HPLC) and reaction intermediates were identified by gas chromatography-mass spectrometry (GC-MS) and followed by different HPLC techniques.

In this paper the fundamentals, main characteristics and recent developments of anodic oxidation and electro-Fenton alone and coupled with other physicochemical processes leading to the photoelectro-Fenton [25,37], peroxicoagulation [38,39] and sonoelectro-Fenton methods are revised, taking into account mainly the work made by the present authors. We will describe the great capacity of oxidation and/or mineralization of all these EAOPs to decontaminate common herbicides and pesticides in acidic aqueous medium.

\section{Experimental}

\section{Chemicals}

All organic pollutants, background electrolytes, acids, catalysts, organic solvents and other chemicals employed were analytical, HPLC or reagent grade from different companies and were used in the electrochemical experiments without further purification. Solutions were prepared with ultra-pure water obtained from a Millipore Milli-Q system with resistivity $>18 \mathrm{M} \Omega \mathrm{cm}$ at room temperature.

\section{Instruments and analytical procedures}

Electrolyses were performed with different potentiostat/galvanostat systems or DC power supplies using three-electrode divided and two-electrode undivided glass cells under controlled-potential and controlled-current electrolysis conditions, respectively. These cells contained Pt or Fe grid or sheet electrodes or a BDD thin-film electrode from CSEM as the anode and an $\mathrm{O}_{2}$-diffusion electrode from E-TEK or a carbon-felt electrode or a graphite bar, both from Carbone Lorraine, as the cathode. The geometric area of all electrodes varied from $3 \mathrm{~cm}^{2}$ to $10 \mathrm{~cm}^{2}$, except for the carbon-felt cathode that a greater geometric area up to $70 \mathrm{~cm}^{2}$ was employed. The photoelectro-Fenton became operative by illuminating the solution with a Philips $6 \mathrm{~W}$ fluorescent black light blue tube placed at the top of the open cell, at $7 \mathrm{~cm}$ above the solution. This tube emitted UVA light in the wavelength region between 300 and $420 \mathrm{~nm}$, with $\lambda_{\max }=360$ $\mathrm{nm}$, supplying a photoionization energy input to the solution of $140 \mu \mathrm{W} \mathrm{cm}$, as detected with a NRC 820 laser power meter working at $514 \mathrm{~nm}$.

The mineralization rate of treated solutions $(100-150 \mathrm{ml})$ was monitored by the abatement of their total organic carbon (TOC) using a Shimadzu VCSN TOC analyzer or by the fall of their chemical oxygen demand (COD) using a French AFNOR NFT-90-101 norm.

Aromatic reaction intermediates were identified by GC-MS technique using a Hewlett-Packard system composed of a HP 5890 Series II gas chromatograph fitted with a HP-5 $0.25 \mu \mathrm{m}$ or a HP-Innowax $0.25 \mu \mathrm{m}$, both of $30 \mathrm{~m} \times 0.25 \mathrm{~mm}$, column and coupled with a HP 5989A mass spectrometer operating in EI mode at 
$70 \mathrm{eV}$. The kinetic decay of initial pollutants and the evolution of their aromatic reaction products were followed by reversed-phase HPLC chromatography using a Waters 600 or a Merck Lachrom HPLC chromatograph fitted with a Spherisorb ODS2 $5 \mu \mathrm{m}, 15 \mathrm{~cm} \times 4.6 \mathrm{~mm}$, or a Purospher RP-18 $5 \mu \mathrm{m}, 25 \mathrm{~cm} \times 4.6 \mathrm{~mm}$, column, respectively, and coupled to the corresponding Waters 996 or L-7455 photodiode array detector selected at the wavelength of their maximum UV-Vis absorption peaks. Generated carboxylic acids were identified and quantified by ion-exclusion HPLC chromatography with the above chromatographic systems fitted with a Biorad Aminex HPX $87 \mathrm{H}, 30 \mathrm{~cm} \times 7.8 \mathrm{~mm}$, column at $35^{\circ} \mathrm{C}$ or a Supelco Supelcogel H $9 \mu \mathrm{m}, 25 \mathrm{~cm} \mathrm{x} 4.6 \mathrm{~mm}$, column at $40{ }^{\circ} \mathrm{C}$, selecting the photodiode detector at $\lambda=210 \mathrm{~nm}$. $\mathrm{H}_{2} \mathrm{O}_{2}$ concentration in electrolyzed solutions was determined from the light absorption of the titanic-hydrogen peroxide colored complex at $\lambda=408 \mathrm{~nm}$ using a Unicam UV4 Prisma double-beam spectrometer thermostated at $25.0{ }^{\circ} \mathrm{C}$.

\section{Results and discussion \\ Anodic oxidation}

Classical anodic oxidation is the most common electrochemical method for the treatment of organic pollutants. This technique utilizes a high $\mathrm{O}_{2}$-overvoltage anode such as $\mathrm{Pt}, \mathrm{PbO}_{2}$ and $\mathrm{BDD}$ to favor the generation of ${ }^{\circ} \mathrm{OH}$ adsorbed at its surface from water oxidation by reaction (1) $[18,19]$. Hydroxyl radical is a very powerful, non-selective, oxidizing agent that reacts rapidly with organic compounds via hydroxylation with addition of a hydroxyl group to a nonsaturated bond or dehydrogenation with the loss of a hydrogen atom, following a radical mechanism until their overall mineralization, i.e., the transformation of initial pollutants into carbon dioxide, water and inorganic ions.

In the comparative examples presented below, anodic oxidation is utilized alone and associated with the electro-Fenton process, where it constitutes the anodic contribution of the electrolytic cell. We will see that the additional production of - OH from classical electro-Fenton using the hydrogen peroxide produced at the cathode enhances significantly the mineralization rate of treated solutions.

\section{Electro-Fenton process}

The electro-Fenton method is an indirect electrooxidation technique with higher oxidation power than anodic oxidation for water remediation. It is an electrochemical advanced oxidation process based on the continuous supply to an acidic contaminated aqueous solution of hydrogen peroxide formed from the two-electron reduction of oxygen gas (reaction (3)) at mercury [21,40], carbonfelt $[11,26,41,42]$ and $\mathrm{O}_{2}$-diffusion $[20,23-25,32,35,36,43]$ cathodes:

$$
\mathrm{O}_{2(\mathrm{~g})}+2 \mathrm{H}^{+}+2 \mathrm{e}^{-} \rightarrow \mathrm{H}_{2} \mathrm{O}_{2}
$$

A small quantity of $\mathrm{Fe}^{2+}$ or $\mathrm{Fe}^{3+}$ ions is then added to the solution to strongly increase the oxidation power of electrogenerated $\mathrm{H}_{2} \mathrm{O}_{2}$. An advantage of the 
electro-Fenton process is the catalytic behavior of the $\mathrm{Fe}^{3+} / \mathrm{Fe}^{2+}$ system: $\mathrm{Fe}^{2+}$ is oxidized by $\mathrm{H}_{2} \mathrm{O}_{2}$ from Fenton's reaction (2) giving rise to hydroxyl radical and $\mathrm{Fe}^{3+}$, whereas $\mathrm{Fe}^{3+}$ thus obtained or initially added to the solution is continuously reduced to $\mathrm{Fe}^{2+}$ from reaction (4) (electrochemical catalysis):

$$
\mathrm{Fe}^{3+}+\mathrm{e}^{-} \rightarrow \mathrm{Fe}^{2+}
$$

Electrochemical reactions (3) and (4) can take place using a three-electrode divided cell or a two-electrode undivided cell. In the first case, the aqueous solution is maintained under oxygen saturation by bubbling compressed air and the main reactions involved in the production of ${ }^{\circ} \mathrm{OH}$ are depicted in Fig. 1 $[21,26,42]$. In the second case, the generation rate of $\mathrm{H}_{2} \mathrm{O}_{2}$ is controlled by means of a carbon polytetrafluoroethylene (PTFE) $\mathrm{O}_{2}$-diffusion cathode $[10,23,36,43]$ or a carbon-felt cathode $[11,22,41]$. Organic pollutants are then oxidized by the combined action of ${ }^{\circ} \mathrm{OH}$ produced at the anode from reaction (1) and in the homogeneous medium from Fenton's reaction (2). Some examples considering the alternative use of $\mathrm{Pt}$ and $\mathrm{BDD}$ anodes under these conditions will be discussed below.

A variant of the electro-Fenton process is the so-called photoelectro-Fenton method, where the treated solution is irradiated with UVA light of $\lambda_{\max }=360 \mathrm{~nm}$ that causes the photo-Fenton reaction of $\mathrm{Fe}(\mathrm{OH})^{2+}$, the predominant species of $\mathrm{Fe}^{3+}$ in acid medium $[5,44]$ :

$$
\mathrm{Fe}(\mathrm{OH})^{2+}+h v \rightarrow \mathrm{Fe}^{2+}+{ }^{\bullet} \mathrm{OH}
$$

Hydroxyl radicals can thus be produced at higher rate by the simultaneous reactions (2) and (5). In addition, complexes of $\mathrm{Fe}^{3+}$ with carboxylic acids generated from the initial pollutants, as oxalic acid, can be quickly photodecomposed into $\mathrm{CO}_{2}$ [44].

Another related electrochemical technique is the so-called peroxi-coagulation method that utilizes a sacrificial iron anode to continuously inject $\mathrm{Fe}^{2+}$ to the solution as follows:

$$
\mathrm{Fe} \rightarrow \mathrm{Fe}^{2+}+2 \mathrm{e}^{-}
$$

A part of $\mathrm{Fe}^{3+}$ ions produced from Fenton's reaction (2) between electrogenerated $\mathrm{Fe}^{2+}$ and $\mathrm{H}_{2} \mathrm{O}_{2}$ then precipitates in the form of $\mathrm{Fe}(\mathrm{OH})_{3}$. In these scenarios organic pollutants can be removed by the direct oxidizing action of ${ }^{\bullet} \mathrm{OH}$, as well as by their coagulation with the $\mathrm{Fe}(\mathrm{OH})_{3}$ precipitate. 


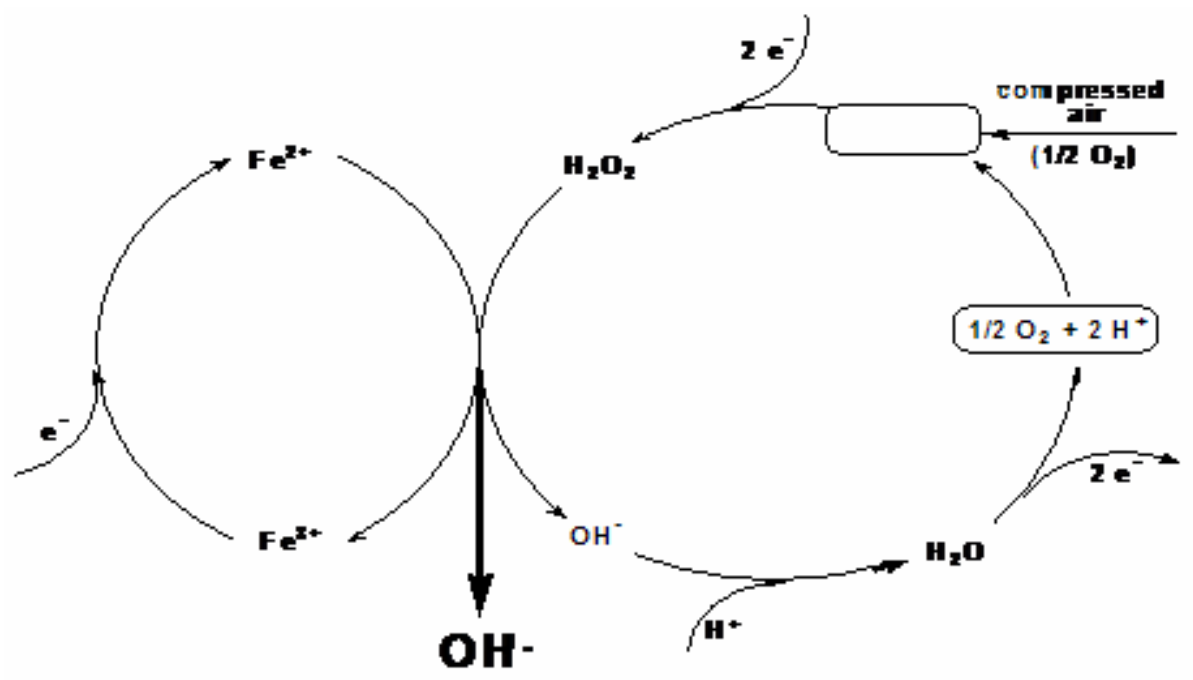

Figure 1. Schematic representation of the main reactions involved in the electro-Fenton process of a divided cell [42].

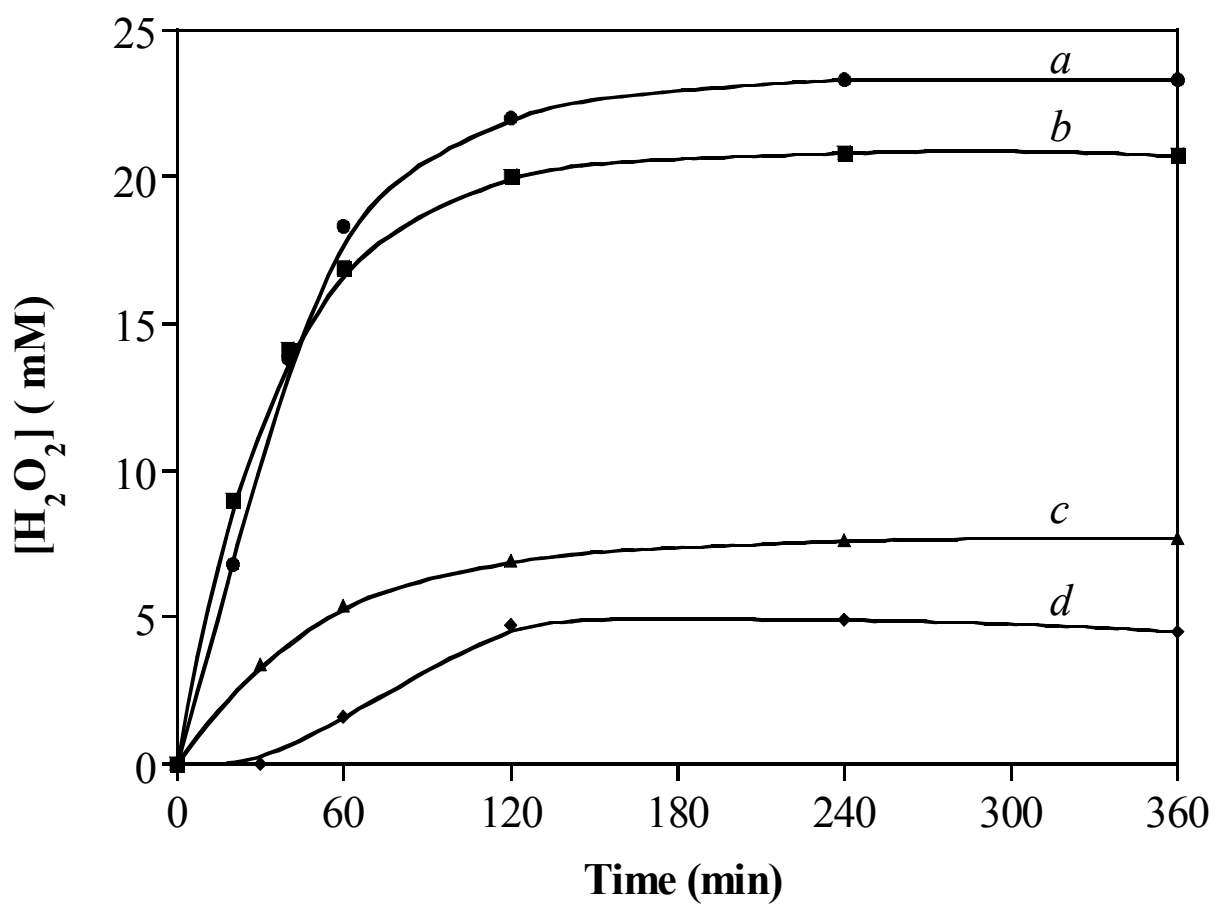

Figure 2. Evolution of the concentration of $\mathrm{H}_{2} \mathrm{O}_{2}$ accumulated in $100 \mathrm{~mL}$ of a $0.05 \mathrm{M}$ $\mathrm{Na}_{2} \mathrm{SO}_{4}$ solution of $\mathrm{pH} 3.0$ with electrolysis time using a $\mathrm{Pt} / \mathrm{O}_{2}$ diffusion cell at constant current. (a) $I=300 \mathrm{~mA}$, (b) $I=300 \mathrm{~mA}$ with $1 \mathrm{mM} \mathrm{Fe}^{2+}$, (c) $I=100 \mathrm{~mA}$ with $1 \mathrm{mM}$ $\mathrm{Fe}^{2+},(d) I=100 \mathrm{~mA}$ with $100 \mathrm{mg} \mathrm{L}^{-1}$ aniline and $1 \mathrm{mM} \mathrm{Fe}^{2+}[43]$.

\section{Degradation of organic pollutants using an undivided cell}

The degradation experiments with a two-electrode undivided cell have been made in most cases with a stirred solution containing $0.05 \mathrm{M} \mathrm{Na}_{2} \mathrm{SO}_{4}$ as background electrolyte in a $\mathrm{H}_{2} \mathrm{SO}_{4}$ medium of $\mathrm{pH}$ near 3.0 by controlled-current 
electrolysis (galvanostatic conditions). Fig. 2 illustrates the evolution of hydrogen peroxide concentration in solution when a $\mathrm{Pt}$ anode and an $\mathrm{O}_{2}$-diffusion cathode are used [43]. The concentration of this electrogenerated species increases with time up to attain a quasi-steady value after $2 \mathrm{~h}$ of electrolysis, just when its generation rate at the $\mathrm{O}_{2}$-diffusion cathode from reaction (3) and its decomposition rate at the Pt anode become equal. The plateau corresponding to the steady-state concentration (curve $a$ ) decreases slightly in the presence of $\mathrm{Fe}^{2+}$ (curve $b$ ), since $\mathrm{H}_{2} \mathrm{O}_{2}$ is consumed by Fenton's reaction (2), and varies proportionally to the applied current. Comparison of curves $c$ and $d$ of Fig. 2 allows concluding that the presence of $100 \mathrm{mg} \mathrm{l}^{-1}$ aniline in solution causes a slight drop of the plateau due to the acceleration of Fenton's reaction (2) by the consumption of ${ }^{\bullet} \mathrm{OH}$ to degrade aniline and its oxidation products.

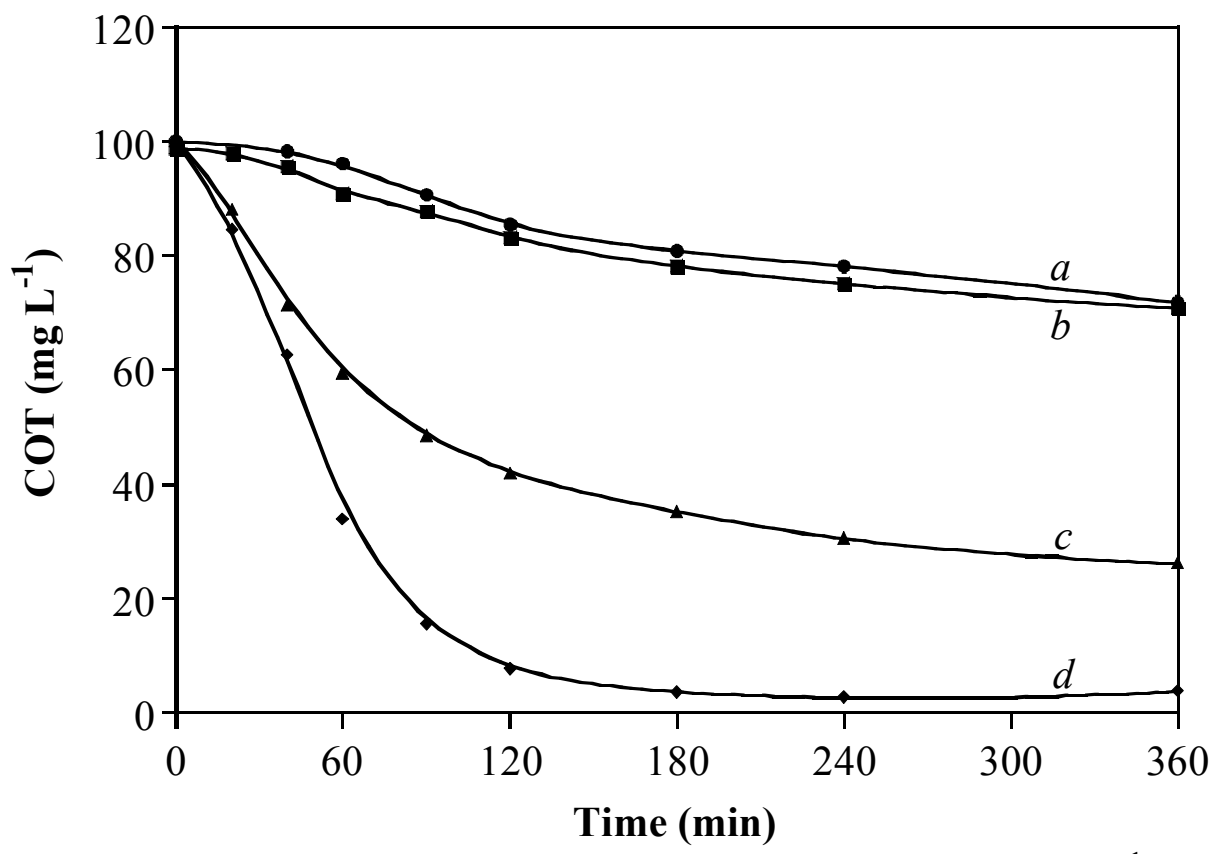

Figure 3. TOC abatement during the treatment of $100 \mathrm{~mL}$ of a $194 \mathrm{mg} \mathrm{L}^{-1} 4-\mathrm{CPA}$ solution with $0.05 \mathrm{M} \mathrm{Na}_{2} \mathrm{SO}_{4}$ of $\mathrm{pH} 3.0$ at $100 \mathrm{~mA}$ and $35^{\circ} \mathrm{C}$ by: $(a)$ anodic oxidation in a Pt/graphite cell, $(b)$ anodic oxidation in a $\mathrm{Pt} / \mathrm{O}_{2}$ diffusion cell, $(c)$ electro-Fenton with $1 \mathrm{mM} \mathrm{Fe}{ }^{2+}$ in a $\mathrm{Pt} / \mathrm{O}_{2}$ diffusion cell, $(d)$ photoelectro-Fenton with $1 \mathrm{mM} \mathrm{Fe}{ }^{2+}$ and UVA light in a $\mathrm{Pt} / \mathrm{O}_{2}$ diffusion cell [20].

The above $\mathrm{Pt} / \mathrm{O}_{2}$ diffusion cell was utilized to determine the degradation rate of several herbicides in aqueous medium from the abatement of their TOC. As an example, Fig. 3 shows the comparative TOC removal found for an aqueous solution of $194 \mathrm{mg} \mathrm{L}^{-1}$ 4-CPA (4-chlorophenoxyacetic acid) of $\mathrm{pH} 3.0$ treated at constant current of $100 \mathrm{~mA}$ by anodic oxidation, electro-Fenton and photoelectro-Fenton [20]. The photoelectro-Fenton method (curve $d$ ) yields a much higher mineralization rate than the electro-Fenton one (curve $c$ ), whereas anodic oxidation in the absence (curve $a$ ) and presence (curve $b$ ) of electrogenerated $\mathrm{H}_{2} \mathrm{O}_{2}$ gives a similar and quite poor mineralization. These results demonstrate that greater amount of reactive ${ }^{\circ} \mathrm{OH}$ is produced in the 
medium from Fenton's reaction (2) than at the Pt surface from reaction (1), thus accounting for by the higher oxidant power of electro-Fenton than anodic oxidation. The positive action of photoelectro-Fenton is due to the photodegradation of complexes of $\mathrm{Fe}^{3+}$ with final carboxylic acids by UVA light. The optimum mineralization rate is found at $\mathrm{pH}$ 3.0. This behavior is general for most aromatic pollutants, which are efficiently degraded at $\mathrm{pH}$ 3-4 by electroFenton and photoelectro-Fenton. In contrast, the change in solution $\mathrm{pH}$ does not affect significantly the degradation rate in anodic oxidation.

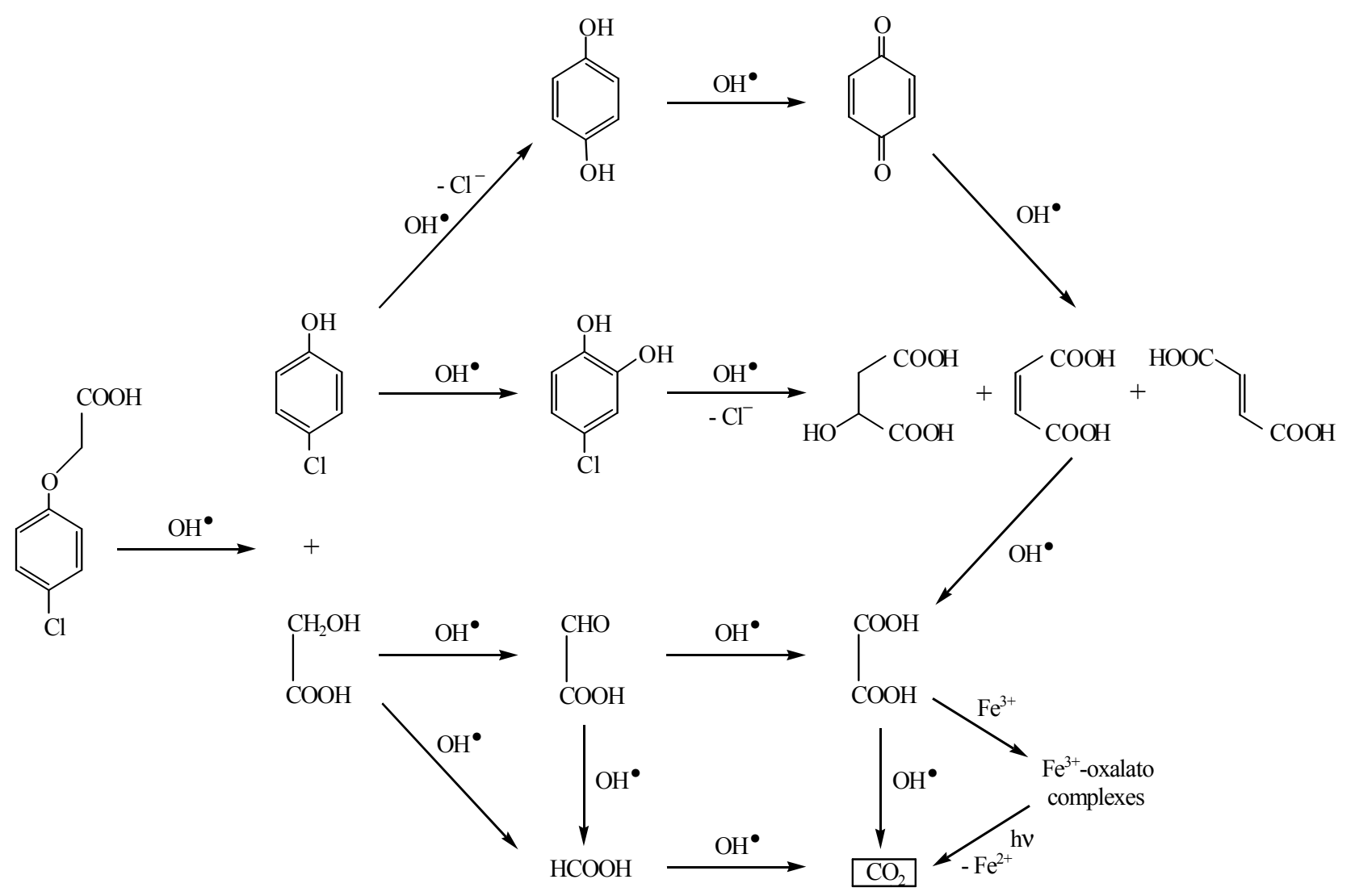

Figure 4. Proposed mineralization reaction sequence for 4-CPA by hydroxyl radicals [20].

Reversed-phase and ion-exclusion HPLC chromatographic analyses of the above electrolyzed solutions revealed the formation of different oxidation products. Aromatic reaction products were also identified by GC-MS. The proposed reaction sequence given in Fig. 4 for the degradation of 4-CPA under the oxidant action of ${ }^{\circ} \mathrm{OH}[20]$ is initiated by the breaking of its $\mathrm{C}(1)-\mathrm{O}$ bond to give 4chlorophenol and glycolic acid. 4-chlorophenol is subsequently transformed into 4-chloro-1,2-dihydroxybenzene, hydroquinone and $p$-benzoquinone. These products are then oxidized to a mixture of malic, maleic and fumaric acids, which are further converted into oxalic acid. The latter acid is also formed from the 
degradation of glycolic acid via glyoxylic acid, yielding formic acid in parallel. Formic acid is directly oxidized to $\mathrm{CO}_{2}$ by ${ }^{\circ} \mathrm{OH}$. In contrast, oxalic acid is very slowly destroyed by this radical in anodic oxidation and forms stable complexes with $\mathrm{Fe}^{3+}$ in electro-Fenton. These $\mathrm{Fe}^{3+}$-oxalato complexes are rapidly photodecarboxylated, with loss of $\mathrm{Fe}^{2+}$ [44], under UVA irradiation in photoelectro-Fenton.

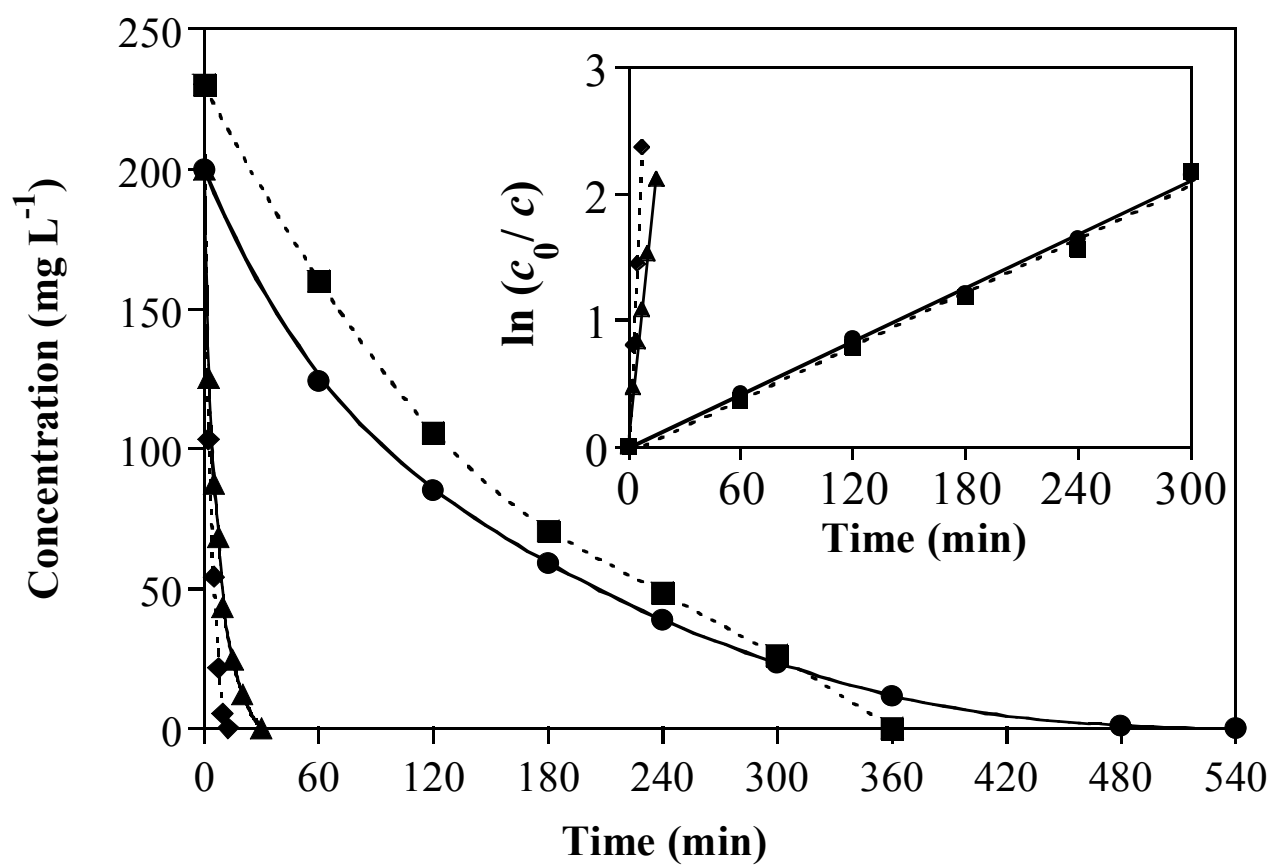

Figure 5. Decay of the concentration of $200 \mathrm{mg} \mathrm{L}^{-1} \mathrm{MCPA}$ and $230 \mathrm{mg} \mathrm{L}^{-1} 2,4-\mathrm{D}$ in aqueous solutions with $0.05 \mathrm{M} \mathrm{Na}_{2} \mathrm{SO}_{4}$ of pH 3.0 at $100 \mathrm{~mA}$ and at $35^{\circ} \mathrm{C}$ during the treatment by: $(\boldsymbol{\bullet}, \mathbf{\square})$ anodic oxidation in a $\mathrm{BDD} /$ graphite cell, $(\boldsymbol{\Lambda}, \boldsymbol{})$ electro-Fenton with $1 \mathrm{mM} \mathrm{Fe}{ }^{2+}$ in a $\mathrm{Pt} / \mathrm{O}_{2}$ diffusion cell. The inset panel shows the corresponding kinetic analysis assuming a pseudo-first-order reaction [23].

\section{Electro-Fenton process with a BDD anode}

The use of a BDD anode instead of a Pt one increases strongly the efficiency of the electro-Fenton process. In this case, very reactive hydroxyl radicals are formed in the medium from Fenton's reaction (2), as well as at the BDD anode surface from reaction (1) due to its higher $\mathrm{O}_{2}$-overvoltage, causing a large acceleration of the oxidation rate of organic pollutants. However, the reactivity of these two kinds of radicals depends on the nature of organics. This can be deduced from Fig. 5, where the comparative decay of two herbicides belonging to the family of chlorophenoxyalcanoic acids, 4-chloro-2methylphenoxyacetic acid (MCPA) and 2,4-dichlorophenoxyacetic acid (2,4-D), at $\mathrm{pH}$ 3.0 treated by electro-Fenton using a $\mathrm{BDD} / \mathrm{O}_{2}$ diffusion cell and anodic oxidation using a $\mathrm{BDD} /$ graphite cell at $100 \mathrm{~mA}$ is presented [23]. As can be seen, both herbicides are rapidly destroyed in 12-30 min by the electro-Fenton method, whereas they need a much longer time (from 360 to $540 \mathrm{~min}$ ) to be removed by anodic oxidation. The very fast drop of MCPA and 2,4-D concentrations in electro-Fenton confirms their quick reaction with ${ }^{\circ} \mathrm{OH}$ in the medium. In contrast, the reaction of both aromatics with ${ }^{\circ} \mathrm{OH}$ adsorbed at the BDD surface taking place in anodic oxidation is much slower. The inset panel of Fig. 5 shows that the decay of both herbicides always follows a pseudo-firstorder kinetics. The TOC vs. consumed specific charge $\left(Q\right.$, in $\left.\mathrm{A} \mathrm{h}^{-1}\right)$ plots for the above 
treatments are depicted in Fig. 6. These results evidence that overall mineralization is attained in all cases because ${ }^{\circ} \mathrm{OH}$ adsorbed on BDD destroys efficiently all final carboxylic acids, although a higher mineralization rate is found for the electro-Fenton method due to the faster reaction of aromatic pollutants with ${ }^{\circ} \mathrm{OH}$ in the medium.

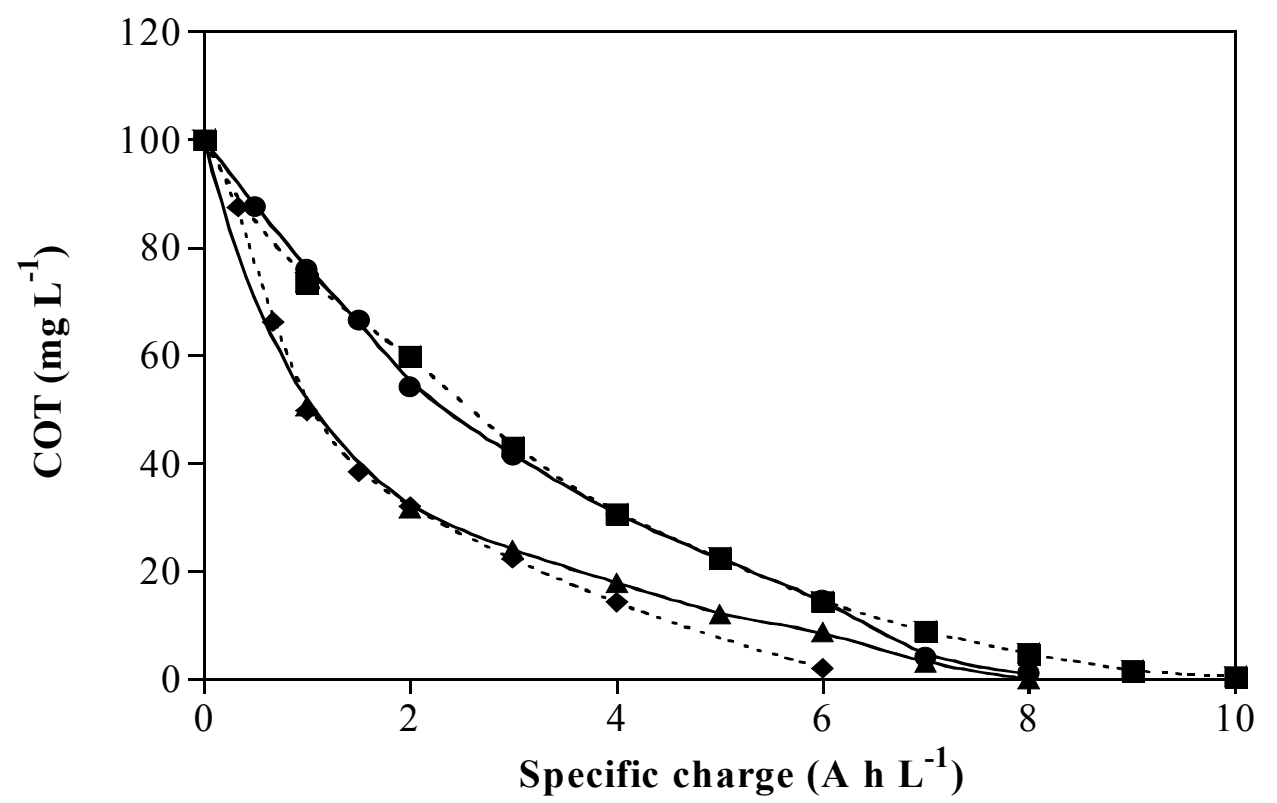

Figure 6. TOC removal for the degradation of $(\boldsymbol{O}, \mathbf{\Delta}) 200 \mathrm{mg} \mathrm{L}^{-1} \mathrm{MCPA}$ and $(\mathbf{\square}, \boldsymbol{\nabla})$ $230 \mathrm{mg} \mathrm{L}^{-1}$ 2,4-D solutions with $0.05 \mathrm{M} \mathrm{Na}_{2} \mathrm{SO}_{4}$ of pH 3.0 at $100 \mathrm{~mA}$ and at $35^{\circ} \mathrm{C}$. $(\bullet, \square)$ Anodic oxidation in a BDD/graphite cell, $(\boldsymbol{\Delta}, \boldsymbol{\vee})$ electro-Fenton with $1 \mathrm{mM} \mathrm{Fe}^{2+}$ in a $\mathrm{Pt} / \mathrm{O}_{2}$ diffusion cell [23].

\section{Electro-Fenton process with an iron anode (peroxi-coagulation method)}

The peroxi-coagulation method utilizes a cell containing a sacrificial iron anode and an $\mathrm{O}_{2}$-diffusion cathode. As can be seen in Fig. 7, this technique is largely effective to decontaminate concentrated solutions of chlorophenoxyalcanoic herbicides such as 4-CPA, MCPA, 2,4-D, dicamba (3,6-dichloro-2methoxybenzoic acid) and 2,4,5-T (2,4,5-trichlorophenoxyacetic acid) [39]. The organic matter is simultaneously removed by its mineralization with ${ }^{\circ} \mathrm{OH}$ produced from Fenton's reaction (2) between $\mathrm{H}_{2} \mathrm{O}_{2}$ and $\mathrm{Fe}^{2+}$ electrogenerated at the cathode (reaction (3)) and anode (reaction (6)), respectively, and by its coagulation with the precipitate of $\mathrm{Fe}(\mathrm{OH})_{3}$ formed from the excess of $\mathrm{Fe}^{3+}$ obtained from Fenton's reaction. 


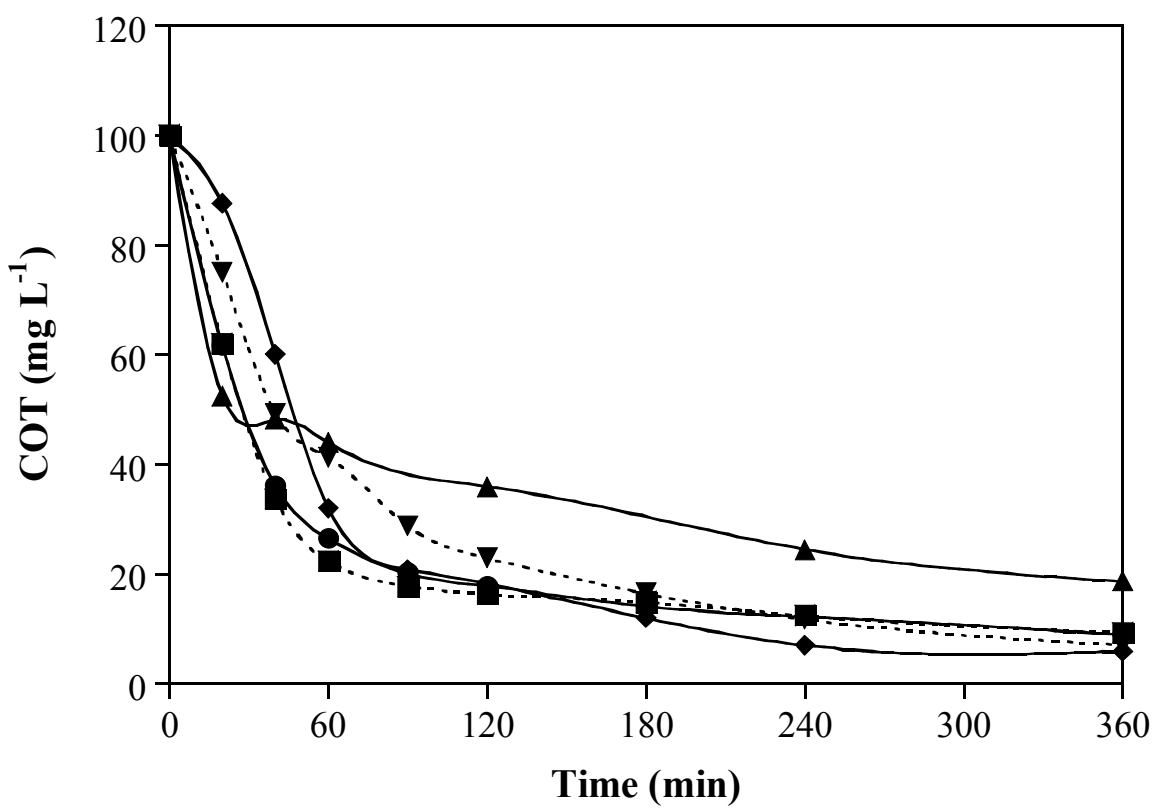

Figure 7. TOC decay with electrolysis time for the peroxi-coagulation degradation of $100 \mathrm{~mL}$ of (O) $200 \mathrm{mg} \mathrm{L}^{-1}$ 4-CPA, (⿴) $194 \mathrm{mg} \mathrm{L}^{-1} \mathrm{MCPA},(\boldsymbol{\Delta}) 230 \mathrm{mg} \mathrm{L}^{-1}$ 2,4-D, ( $)$ $230 \mathrm{mg} \mathrm{L}^{-1}$ dicamba and $(\boldsymbol{\nabla}) 269 \mathrm{mg} \mathrm{L}^{-1} 2,4,5$-T solutions with $0.05 \mathrm{M} \mathrm{Na}_{2} \mathrm{SO}_{4}$ of $\mathrm{pH}$ 3.0 at $100 \mathrm{~mA}$ and at $35^{\circ} \mathrm{C}$ using an $\mathrm{Fe} / \mathrm{O}_{2}$ diffusion cell [39].

\section{Electro-Fenton process with a Pt/carbon felt cell}

The carbon-felt electrode has a high specific surface. An interesting characteristic of this cathode is that it can generate both components of the Fenton's reagent $\left(\mathrm{H}_{2} \mathrm{O}_{2}\right.$ and $\left.\mathrm{Fe}^{2+}\right)$, but hydroxyl radicals are produced from Fenton's reaction (2) in the bulk solution. This allows keeping an efficient concentration of $\mathrm{Fe}^{2+}$ in solution from reaction (4), giving rise to a rapid destruction of organic compounds, as exemplified in Fig. 8 for the herbicide diuron. Fig. 8 also shows the significant role that plays the applied current on the degradation rate of organic pollutants. A faster decay kinetics for diuron with increasing current can be observed [46]. At the highest current of $300 \mathrm{~mA}$, the complete degradation of $0.17 \mathrm{mM}$ diuron is attained in only $6 \mathrm{~min}$, but this time becomes gradually longer when applied current decreases.

At present it is well-known that the solution $\mathrm{pH}$ is an important control parameter of the effectiveness of the electro-Fenton process. Several authors have reported that a $\mathrm{pH}$ value close to 3 yields the maximum efficiency for Fenton's reagent and consequently, for the electro-Fenton process. The nature of the inorganic acid used to adjust the solution $\mathrm{pH}$ can also play a significant role on the oxidation power of this technique. Fig. 9 illustrates the effect of $\mathrm{pH}$ and the nature of the medium on the mineralization rate of $0.2 \mathrm{mM}$ methyl parathion (an organophosphorus herbicide) [47]. A faster TOC abatement can be observed at $\mathrm{pH} 3.0$ in comparison to $\mathrm{pH} 4.0$ and 1.0 in both sulphate and perchlorate media. In all $\mathrm{pH}$ values the perchlorate solutions are more rapidly decontaminated. After $9 \mathrm{~h}$ of electrolysis, the solution TOC is reduced by approximately $100 \%$ at $\mathrm{pH}$ 3.0 in perchlorate medium. The mineralization rate is slightly slower at $\mathrm{pH} 4.0$, where the precipitation of $\mathrm{Fe}^{3+}$ in the form of $\mathrm{Fe}(\mathrm{OH})_{3}$ is initiated, but it becomes 
insignificant at $\mathrm{pH} 1.0$ when $\mathrm{Fe}^{2+}$ ions form complexes with $\mathrm{H}_{2} \mathrm{O}_{2}$ and $\mathrm{SO}_{4}{ }^{2-}$ ions. A similar behavior is found for media containing $\mathrm{HCl}$.

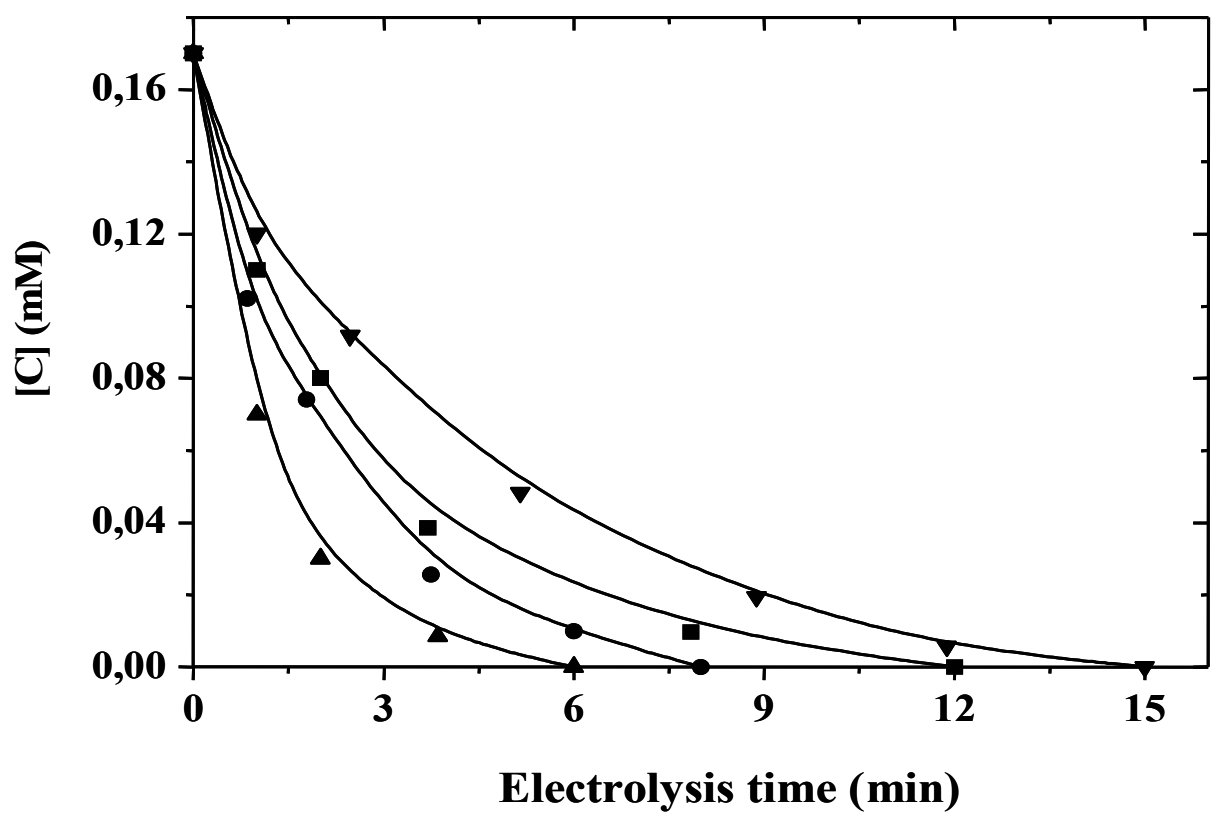

Figure 8. Decay kinetics for the herbicide diuron $\left(C_{0}=0.17 \mathrm{mM}\right)$ in $150 \mathrm{~mL}$ of an aqueous solution with $0.05 \mathrm{M} \mathrm{Na}_{2} \mathrm{SO}_{4}$ and $0.5 \mathrm{mM} \mathrm{Fe}^{3+}$ of $\mathrm{pH} 3.0$ using a Pt/carbon felt cell at ( $\boldsymbol{\nabla}) 60 \mathrm{~mA},(\boldsymbol{\nabla}) 100 \mathrm{~mA},(\bullet) 200 \mathrm{~mA},(\boldsymbol{\Delta}) 300 \mathrm{~mA}$ [46].

\section{Degradation of organic pollutants using a divided cell}

These experiments were carried out with a three-electrode cell containing 125 $\mathrm{mL}$ of a solution acidified with $\mathrm{H}_{2} \mathrm{SO}_{4}$, a carbon felt as working electrode (cathode), a Pt sheet as auxiliary electrode (anode) and a saturated calomel electrode (SCE) as reference electrode. Electrolyses were performed by controlling the cathodic potential $\left(E_{\mathrm{app}}=-0.5 \mathrm{~V} / \mathrm{SCE}\right)$ or by applying a controlled variable current.

The mineralization kinetics of an aqueous solution with $1 \mathrm{mM}$ 2,4-D treated by electro-Fenton with a carbon-felt cathode is presented in Fig. 10. An almost total mineralization ( $>95 \%$ TOC removal) can be observed after the consumption of 2000 C [11]. Reversed-phase HPLC analysis of treated solutions allowed the detection of some primary hydroxylated derivatives formed at the early stages of the treatment such as 2,4-dichlorophenol, 2,4-dichlororesorcinol, 4,6dichlororesorcinol, 2-chlorohydroquinone and 1,2,4-trihydroxybenzene. The presence of these derivatives in the reaction medium confirms the attack of hydroxyl radical on the aromatic ring of 2,4-D leading to the formation of its hydroxylated derivatives and other processes, as dechlorination and dehydrogenation. The primary derivatives can also react with ${ }^{\circ} \mathrm{OH}$, similarly to 2,4-D, to give polyhydroxylated compounds and quinones before undergoing the attack of the oxidant to open the benzene moiety producing short-chain carboxylic acids. 


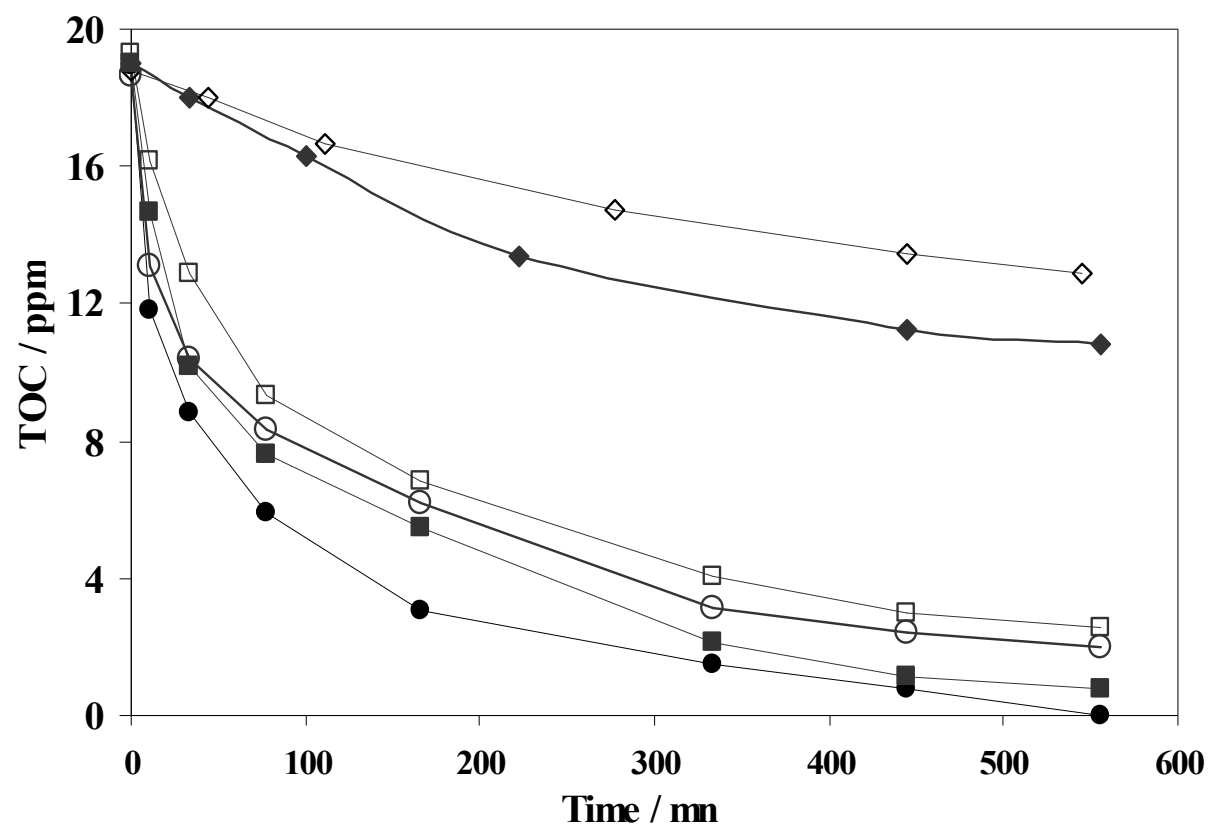

Figure 9. Effect of $\mathrm{pH}$ and the reaction medium on TOC abatement of $150 \mathrm{~mL}$ of a 0.2 $\mathrm{mM}$ methyl parathion solution with $0.1 \mathrm{mM} \mathrm{Fe}^{3+}$ degraded in a $\mathrm{Pt} /$ carbon felt cell at 150

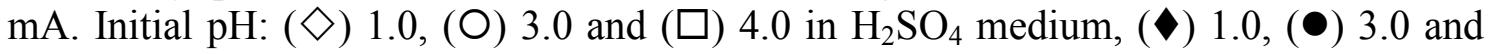
(匹) 4.0 in $\mathrm{HClO}_{4}$ medium [47].

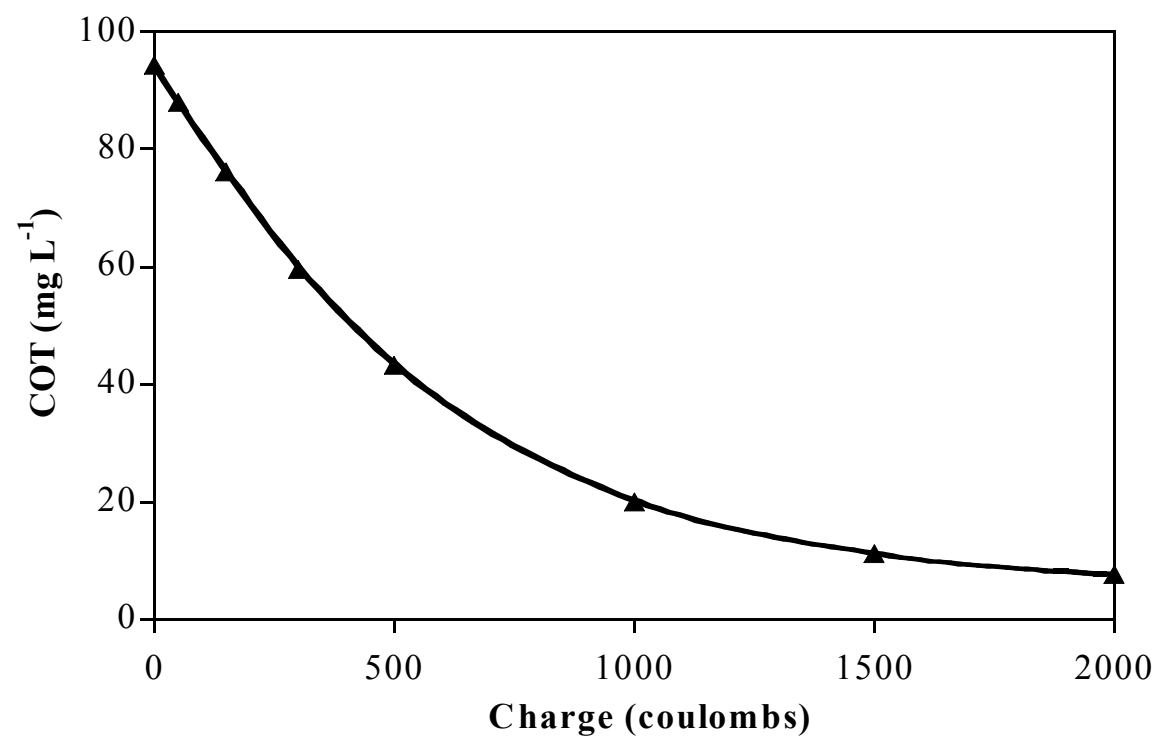

Figure 10. Variation of TOC with consumed electrical charge for the treatment of 125 $\mathrm{mL}$ of a $1 \mathrm{mM} 2,4-\mathrm{D}$ solution with $1 \mathrm{mM} \mathrm{Fe}^{3+}$ of $\mathrm{pH} 3.0$ by electro-Fenton in a threeelectrode cell by applying a cathodic potential of $E_{\text {app }}=-0.5 \mathrm{~V} / \mathrm{SCE}$ [11].

\section{Treatment of pesticides commercial formulations}

The electro-Fenton method has also shown an excellent ability to decompose aqueous solutions of commercial formulations of pesticides such as Mistel GD (fungicide of Novartis Agro) and Cuprofix (fungicide of ELF Atochem Agri) [22]. Mistel GD is a mixture of the active principles cymoxanil and mancozebe 
along with additives, whereas Cuprofix contains cymoxanil, zinebe, $\mathrm{CuSO}_{4}$ and surfactants as additives. Reversed-phase HPLC chromatographic analysis of a Mistel GD solution treated in a Pt/carbon felt cell by electro-Fenton at $100 \mathrm{~mA}$ reveals that cymoxanil and mancozebe are rapidly removed after electrolysis times of 90 and 140 min, respectively (see Fig. 11). Taking into account the complex consumption of hydroxyl radicals by the additives, these removal times seem reasonable. Fig. 11 also shows that the use of either $\mathrm{Fe}^{3+}$ or $\mathrm{Cu}^{2+}$ as catalyst leads to practically the same decay rate, although it is slightly higher for $\mathrm{Cu}^{2+}$. In contrast, the catalytic action of $\mathrm{Fe}^{2+}$ on $\mathrm{H}_{2} \mathrm{O}_{2}$ is more effective than $\mathrm{Cu}^{+}$for $\mathrm{COD}$ reduction, since $92 \%$ and $80 \%$ of mineralization is attained for the same Mistel GD solution with $\mathrm{Fe}^{3+}$ and $\mathrm{Cu}^{2+}$, respectively, after the consumption of $6000 \mathrm{C}$ at $300 \mathrm{~mA}$. The positive catalytic action of $\mathrm{Cu}^{2+}$ in the electro-Fenton method has also been corroborated in the treatment of a Cuprofix solution without addition of $\mathrm{Fe}^{3+}$. Under these conditions, zinebe and cymoxanil, the active principles of Cuprofix, are completely removed from the medium in 70 and $150 \mathrm{~min}$, respectively, by applying a constant current of $100 \mathrm{~mA}$ [22]. As can be seen in Fig. 12, Cuprofix can be completely mineralized when electrolysis is prolonged up to the consumption of a charge of $10000 \mathrm{C}$, that is, after $8 \mathrm{~h}$ of treatment at $350 \mathrm{~mA}$. The mineralization rate is slightly higher when $\mathrm{Fe}^{3+}$ is added as catalyst.

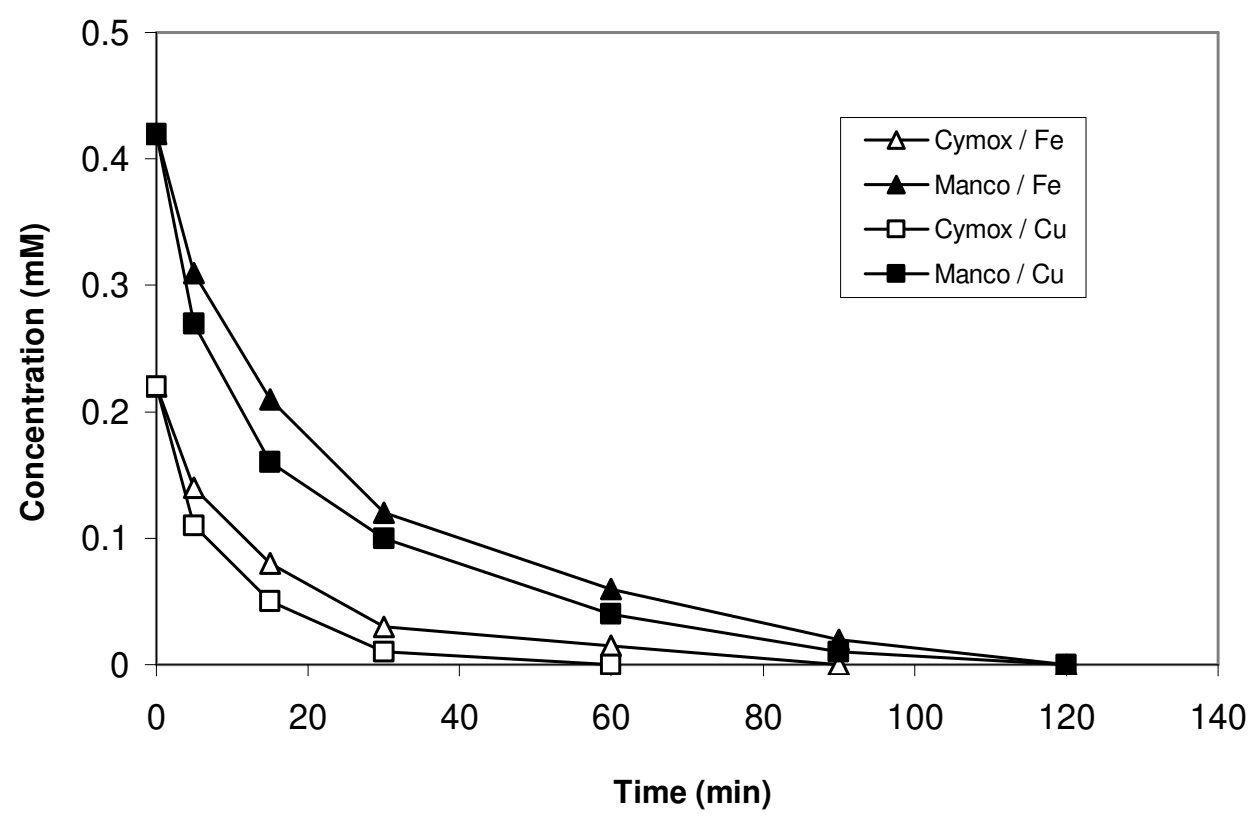

Figure 11. Effect of $(\Delta, \boldsymbol{\Delta}) 1 \mathrm{mM} \mathrm{Fe}^{3+}$ and $(\square, \boldsymbol{\square}) 1 \mathrm{mM} \mathrm{Cu}^{2+}$ as catalyst on the timecourse of $(\Delta, \square)$ cymoxanil and $(\boldsymbol{\Lambda}, \boldsymbol{\square})$ mancozebe concentrations contained in a Mistel GD solution treated by electro-Fenton in a Pt/carbon felt cell at $100 \mathrm{~mA}$ [22]. 


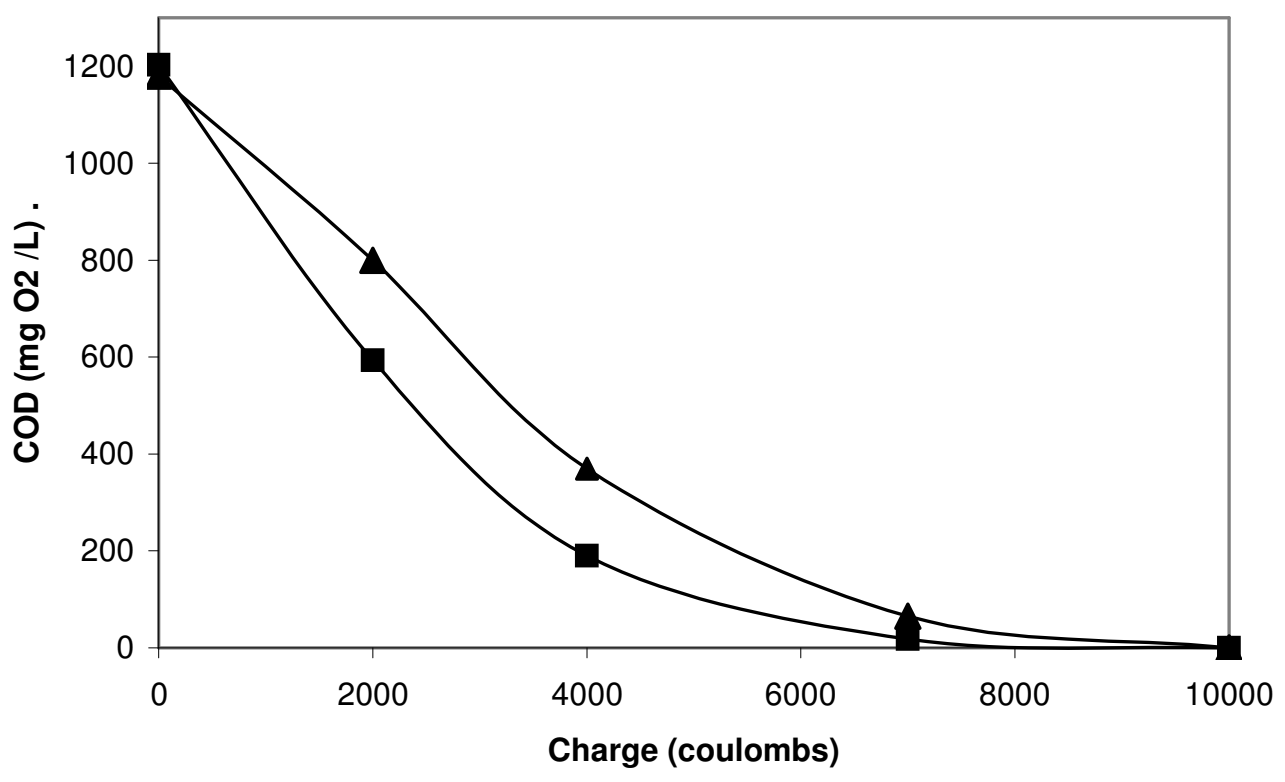

Figure 12. COD abatement with consumed electrical charge for the electro-Fenton treatment of a Cuprofix solution $(\boldsymbol{\Delta})$ without catalyst and $(\boldsymbol{\square})$ in the presence of $1 \mathrm{mM}$ $\mathrm{Fe}^{3+}$ using a Pt/carbon felt cell at $350 \mathrm{~mA}$ for $8 \mathrm{~h}$ [22].

\section{Electro-Fenton coupled to sonolysis (sonoelectro-Fenton)}

This new method corresponds to the coupling of electro-Fenton with the simultaneous irradiation of ultrasounds. Organic pollutants can then be destroyed by the combined action of ${ }^{\bullet} \mathrm{OH}$ generated by Fenton's reaction (2) and different processes caused by the ultrasounds such as pyrolysis in cavitation bubbles and oxidation by ${ }^{\bullet} \mathrm{OH}$ formed from water sonolysis:

$$
\mathrm{H}_{2} \mathrm{O} \stackrel{\text { ultrasounds }}{\longrightarrow} \mathrm{H}^{\bullet}+{ }^{\bullet} \mathrm{OH}
$$

The cell employed in sonoelectro-Fenton is a three-electrode divided cell, identical to that described above for classical electro-Fenton. The ceramic producing the ultrasounds is placed below the base of the electrochemical cell and such irradiation is transmitted to the solution treated by electro-Fenton through a transductor. In this way solutions are submitted to ultrasonic irradiations of high frequency (460 and $465 \mathrm{kHz}$ ) and low frequency $(\approx 28 \mathrm{kHz})$, with powers of 20,60 and $80 \mathrm{~W}$.

Fig. 13 presents the evolution of 2,4-D concentration during comparative electroFenton and sonoelectro-Fenton treatments. A clear increase in degradation rate for high and low frequencies in comparison to the electrolysis alone can be observed. Since the application of sonolysis alone does not yield a signification degradation of 2,4-D, one can infer that the faster degradation found using sonoelectro-Fenton is rather due to the mechanical effects of ultrasounds (increase in the transport rate of electroactive species towards the working electrode), instead of chemical effects (e.g., production of ${ }^{\circ} \mathrm{OH}$ by sonolysis from reaction (7)). Fig. 13 also shows that the degradation rate using ultrasounds of 80 
W becomes lower than that of electro-Fenton. This loss in mineralization ability of the sonoelectro-Fenton system could be related to a degasification effect of the solution that causes a significant decay in $\mathrm{O}_{2}$ concentration near the cathode, thus decreasing the electrogeneration of $\mathrm{H}_{2} \mathrm{O}_{2}$ from reaction (3) and the formation of oxidant ${ }^{\circ} \mathrm{OH}$ from Fenton's reaction (2).

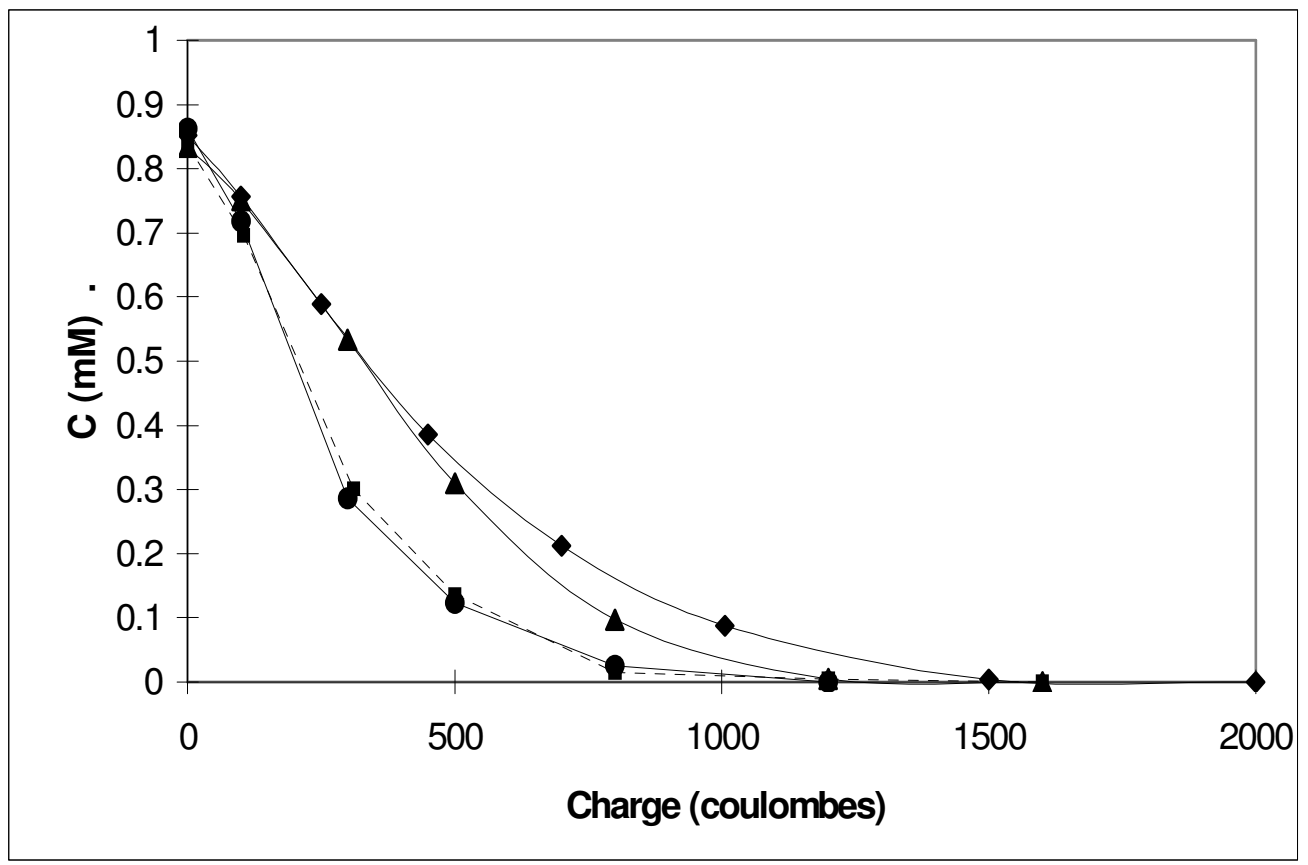

Figure 13. 2,4-D concentration decay vs. consumed electrical charge for $125 \mathrm{~mL}$ of about $0.85 \mathrm{mM}$ herbicide solutions with $\mathrm{H}_{2} \mathrm{SO}_{4}$ and $1 \mathrm{mM} \mathrm{Fe}^{3+}$ of $\mathrm{pH} 3.0$ treated by $(\boldsymbol{\Delta})$ electro-Fenton alone and sonoelectro-Fenton with an ultrasound power of (ם) $20 \mathrm{~W}$, (๑) $60 \mathrm{~W},(\diamond) 80 \mathrm{~W}$. In all cases a three-electrode cell was used by applying a cathodic potential of $E_{\text {app }}=-0.5 \mathrm{~V} / \mathrm{SCE}$.

\section{Conclusions}

The electro-Fenton method seems very attractive by its ability to efficiently destroy organic micropollutants of waters contaminated with persistent organic pollutants (POPs), particularly herbicides and pesticides. It is usually applied with a $\mathrm{Pt}$ anode, but other anodic materials such as $\mathrm{PbO}_{2}, \mathrm{BDD}$ (with much higher $\mathrm{O}_{2}$-overvoltage) or even iron (sacrificial anode) can also be utilized in divided or undivided cells. Different catalysts including salts of $\mathrm{Fe}^{2+}, \mathrm{Fe}^{3+}$ and $\mathrm{Cu}^{2+}$ alones or combined can be used to produce hydroxyl radical by reaction with hydrogen peroxide electrogenerated at a carbon-felt or $\mathrm{O}_{2}$-diffusion cathode. The degradation and mineralization reactions of herbicides and pesticides with this radical shown in this paper always obey a pseudo-first-order kinetics. Intermediate reaction products formed during all treatments are also mineralized. The final electrolyzed solutions contain only inorganic ions, along with shortchain carboxylic acids when overall mineralization is not attained.

In this paper we show that the electro-Fenton method can be easily coupled to other degradation techniques involving photochemistry (photoelectro-Fenton), 
sonochemistry (sonoelectro-Fenton) or electrocoagulation (peroxi-coagulation) to enhance the mineralization ability of treated solutions. Thus, the alternative use of photoelectro-Fenton or sonoelectro-Fenton leads to a positive synergic effect on the degradation rate of herbicides.

Finally, we can remark that the electro-Fenton method is an ecological technique because it can yield the total mineralization of POPs without addition of toxic chemical reagents and without production of dangerous wastes. The application of this procedure is inexpensive due to its low operational energy cost.

\section{References}

1. E. Oliveros, O. Legrini, M. Hohl, T. Muller, A.M. Braun, Chem. Eng. Process 36 (1997) 397.

2. J. De Laat, H. Galard, Environ. Sci. Technol. 33 (1999) 2726.

3. $\quad$ E. Neyens, J. Baeyens, J. Hazard. Mat. B98 (2003) 33.

4. K.C. Namkung, A.E. Burgesse, D.H. Bremner, Environ. Technol. 26 (2003) 34.

5. J.J. Pignatello, Environ. Sci. Technol. 26 (1992) 944.

6. O. Legrini, E. Oliveros, A.M. Braun, Chem. Rev. 93 (1993) 671.

7. S. Malato, J. Blanco, Ch. Richter, M.I. Maldonado, Appl. Catal. B: Environ. 25 (2000) 31.

8. D. Robert, S. Malato, Sci. Tot. Environ. 291 (2002) 85.

9. $\quad$ Y. Sun, J.J. Pignatello, Environ. Sci. Technol. 27 (1993) 304.

10. E. Brillas, E. Mur, R. Sauleda, L. Sanchez, J. Peral, X. Domènech, J. Casado, Appl. Catal. B: Environ. 16 (1998) 31.

11. M.A. Oturan, J. Appl. Electrochem. 30 (2000) 475.

12. Ch. Comninellis, C. Pulgarin, J. Appl. Electrochem. 21 (1991) 703.

13. D. Arapoglou, A. Vlyssides, C. Israilides, A. Zorpas, P. Karlis, J. Hazard. Mat. 98 (2003) 191.

14. T. Harrington, D. Pletcher, J. Electrochem. Soc. 146 (1999) 2983.

15. G.V. Buxton, C.L. Greenstock, W.P. Helman, A.B. Ross, J. Phys. Chem. Ref. Data 17 (1988) 513.

16. Ch. Comninellis, Electrochim. Acta 39(1994) 1857.

17. N. Belhadj Tahar, A. Savall, J. Electrochem. Soc. 145 (1998) 3427.

18. E. Brillas, I. Sirés, C. Arias, P.L. Cabot, F. Centellas, R.M. Rodríguez, J.A. Garrido, Chemosphere 58 (2005) 399.

19. F. Montilla, P.A. Michaud, E. Morallón, J.L. Vázquez, Ch. Comninellis, Electrochim. Acta 47 (2002) 3509.

20. B. Boye, M.M. Dieng, E. Brillas, Environ. Sci. Technol. 36 (2002) 3030.

21. M.A. Oturan, J. Pinson, J. Phys. Chem. 99 (1995) 139484.

22. N. Oturan, M.A. Oturan, Agron. Sustain. Dev. 25 (2005) 267.

23. E. Brillas, B. Boye, I. Sirés, J.A. Garrido, R.M. Rodríguez, C. Arias, P.L. Cabot, Ch. Comninellis, Electrochim. Acta 49 (2004) 4487.

24. I. Sirés, J.A. Garrido, R.M. Rodríguez, E. Brillas, N. Oturan, M.A. Oturan, Appl. Catal. B: Environ. in press

25. E. Brillas, M.A. Baños, J.A. Garrido, Electrochim. Acta 48 (2003) 1697. 
26. M.A. Oturan, J.J. Aaron, N. Oturan, J. Pinson, Pestic. Sci. 55 (1999) 558.

27. J.J. Aaron, M.A. Oturan, Turk. J. Chem. 25 (2001) 5090.

28. E. Brillas, M.A. Baños, S. Camps, C. Arias, P.L. Cabot, J.A. Garrido, R.M. Rodríguez, New J. Chem. 28 (2004) 314.

29. K. Hanna, S. Chiron, M.A. Oturan, Water Res. 39 (2005) 2763.

30. E. Guivarch, N. Oturan, M.A. Oturan, Environ. Chem. Lett. 1 (2003) 165.

31. E. Guivarch, S. Trévin, C. Lahitte, M.A. Oturan, Environ. Chem. Lett. 1 (2003) 39.

32. C. Flox, S. Ammar, C. Arias, E. Brillas, A.V. Vargas-Zavala, R. Abdelhedi, Appl. Catal. B: Environ. 67 (2006) 93.

33. B. Gözmen, M.A. Oturan, N. Oturan, O. Erbatur, Environ. Sci. Technol. 37 (2003) 3716.

34. N. Bellakhal, M.A. Oturan, N. Oturan, M. Dachraoui, Environ. Chem. 3 (2006) 345.

35. I. Sirés, J.A. Garrido, R.M. Rodríguez, P.L. Cabot, F. Centellas, C. Arias, E. Brillas, J. Electrochem. Soc. 153 (2006) D1.

36. I. Sirés, C. Arias, P.L. Cabot, F. Centellas, J.A. Garrido, R.M. Rodríguez, E. Brillas, Chemosphere 66 (2007) 1660.

37. B. Boye, M.M. Dieng, E. Brillas, J. Electroanal. Chem. 557 (2003) 135.

38. B. Boye, M.M. Dieng, E. Brillas, Electrochim. Acta 48 (2003) 781.

39. E. Brillas, B. Boye, M.A. Baños, J.C. Calpe, J.A. Garrido, Chemosphere 51 (2003) 227.

40. M.A. Oturan, J. Pinson, J. Bizot, D. Deprez, B. Terlain, J. Electroanal. Chem. 334 (1992) 103.

41. M.A. Oturan, J.-L. Peiroten, P. Chartrin, J.A. Aurel, Environ. Sci. Technol. 34 (2000) 3474.

42. M.A. Oturan, N. Oturan, C. Lahitte, S. Trevin, J. Electroanal. Chem. 507 (2001) 96.

43. E. Brillas, E. Mur, J. Casado, J. Electrochem. Soc. 144 (1996) 2374.

44. Y. Zuo, J. Hoigné, Environ. Sci. Technol. 26 (1992) 1014.

45. E. Brillas, B. Boye, M.M. Dieng, J. Electrochem. Soc. 150 (2003) E148.

46. M.C. Edelahi, N. Oturan, M.A. Oturan, Y. Padellec, A. Bermond, K. El Kacemi, Environ. Chem. Lett. 1 (2004) 233.

47. M. Diagne, N. Oturan, M.A. Oturan, Chemosphere 66 (2007) 841. 